\title{
International Unit per Square Meter
}

National Cancer Institute

\section{Source}

National Cancer Institute. International Unit per Square Meter. NCI Thesaurus. Code C67378.

A dose calculation unit expressed as a number of arbitrary units of biological activity (International Units) of substance per square meter of body surface area. 